\title{
ANALISIS PENGARUH UKURAN PERUSAHAAN, PROFITABILITAS, LIKUIDITAS TERHADAP STRUKTUR MODAL PADA PERUSAHAAN JASA SEKTOR KEUANGAN PERBANKAN YANG TERDAFTAR DI BURSA EFEK INDONESIA PADA TAHUN 2014 - 2018
}

\author{
Natashia \\ Program Studi Magister Manajemen Universitas Tarumanagara \\ natashia.wong@gmail.com \\ Indra Widjaja \\ Program Studi Magister Manajemen Universitas Tarumanagara \\ Masuk : 06-12-2019, revisi : 21-12-2019 diterima untuk diterbitkan : 23-12-2019
}

\begin{abstract}
An optimal capital structure is an important financial result because it increases the performance and value of a company. Good company performance on stock prices in the capital market, so that returns obtained by shareholders can be obtained optimally. In making decisions about companies consider several factors before choosing both internal and external namely: company size, profitability and liquidity. In this study, shows the size of the company, profitability and liquidity of the company's capital structure in $2014-2018$.
\end{abstract}

Keywords : Profitability; Liquidity; Company Size; Capital Structure

Abstrak : Struktur modal yang optimal merupakan keputusan keuangan yang penting karena mempengaruhi kinerja dan nilai sebuah perusahaan. Kinerja perusahaan yang bagus berdampak pada harga saham di pasar modal, sehingga return yang diperoleh oleh para pemegang saham dapat tercapai optimal. Dalam melakukan keputusan pendanaan perusahaan mempertimbangkan beberapa faktor sebelum memilih pendanaan baik dari internal maupun eksternal yaitu: ukuran perusahaan, profitabilitas dan likuiditas. Dalam penelitian ini menunjukkan pengaruh ukuran perusahaan, profitabilitas dan likuiditas terhadap struktur modal perusahaan jasa sektor keuangan perbankan tahun $2014-2018$.

Kata Kunci : Profitabilitas; Likuiditas; Ukuran Perusahaan; Struktur Modal

\section{Latar Belakang}

Suatu perusahaan dalam menjalankan usahanya sejalan dengan perkembangan yang dialami selalu membutuhkan modal yang digunakan untuk membiayai dalam kegiatan operasional perusahaan itu sehari-hari, baik untuk melakukan investasi maupun untuk keperluan lainnya. Besar kecilnya modal yang dibutuhkan oleh suatu perusahaan tergantung dari besar kecilnya biaya yang dikeluarkan oleh perusahaan itu sendiri.

Dalam melakukan keputusan pendanaan perusahaan mempertimbangkan beberapa faktor sebelum memilih pendanaan baik dari internal maupun external yaitu; profitabilitas, size, growth, tangibility, nondebt tax shield, tax, volatilitas, dan likuiditas. Dengan mengetahui faktorfaktor yang paling mempengaruhi struktur modal pihak manajemen dapat menentukan bagaimana seharusnya pemenuhan dana untuk mencapai struktur modal yang optimal. Menurut Brigham dan Houston (2007) struktur modal yang optimum adalah struktur yang memaksimalkan harga 4 saham perusahaan. Oleh karena itu struktur modal harus disesuaikan dengan keadaan perusahaan. Struktur modal yang optimal adalah struktur modal yang mengoptimalkan keseimbangan antara resiko dan pengembalian sehingga memaksimumkan harga saham. Tujuan dilakukan penelitian ini adalah untuk memperoleh bukti empiris 
mengenai Pengaruh signifikan dari ukuran penelitian, profitabilitas dan likuiditas pada perusahaan jasa sektor keuangan perbankan yang terdaftar di Bursa Efek Indonesia pada tahun $2014-2018$

\section{Kajian Teori}

\section{Ukuran Perusahaan}

Ukuran perusahaan sering dijadikan indikator bagi kemungkinan terjadinya kebangkrutan bagi suatu perusahaan, dimana perusahaan dengan ukuran lebih besar dipandang lebih mampu menghadapi krisis dalam menjalankan usahanya. Hal ini akan mempermudah perusahaan dengan ukuran lebih besar untuk memperoleh pinjaman atau dana eksternal, serta menunjukkan adanya hubungan positif antara ukuran perusahaan dengan leverage.

$$
\text { SIZE }=\text { Ln (Total Asset) }
$$

\section{Profitabilitas}

Rasio Profitabilitas (Profitability Ratio) adalah rasio atau perbandingan untuk mengetahui kemampuan perusahaan untuk mendapatkan laba (profit) dari pendapatan (earning) terkait penjualan, aset dan ekuitas berdasarkan dasar pengukuran tertentu. Net Profit Margin atau Marjin Laba Bersih merupakan rasio profitabilitas untuk menilai persentase laba bersih yang didapat setelah dikurangi pajak terhadap pendapatan yang diperoleh dari penjualan.

$$
\text { Net Profit Margin }=\frac{\text { Earning After Tax }}{\text { Sales }}
$$

\section{Likuiditas}

Rasio likuiditas adalah rasio yang menunjukkan kemampuan perusahaan dalam memenuhi kewajiban atau membayar utang jangka pendeknya. Dalam penelitian ini, penulis menggunakan LDR (Loan to Deposit Ratio). LDR adalah rasio antara total volume kredit dibagi dengan jumlah total penerimaan dana yang dimiliki. Hasil dari penghitungan tersebut biasanya dalam satuan persen. Rasio yang didapatkan dapat dijadikan indikasi tingkat kemampuan sebuah bank konvensional dalam menyalurkan dana yang berasal dari masyarakat. Penyaluran dana dapat dilakukan melalui beberapa jenis produk perbankan seperti tabungan, giro, deposito berjangka, sertifikat deposito berjangka, dan kewajiban segera lainnya.

$$
\text { Loan to Deposit Ratio }=\frac{\text { Total Volume Kredit }}{\text { Total Penerimaan Dana }}
$$

\section{Struktur Modal}

Menurut Riyanto (2001) dalam Kartika (2009), struktur modal adalah perimbangan antara jumlah hutang jangka panjang dengan ekuitas atau modal sendiri yang dimiliki perusahaan. Sedangkan menurut Mardiyanto (2008) dalam struktur modal, utang jangka pendek tidak diperhitungkan karena jenis utang ini pada umumnya bersifat spontan (maskudnya berubah-berubah sesuai dengan perubahan tingkat penjualan), sedangkan utang jangka panjang bersifat tetap selama jangka waktu yang relatif lebih panjang (biasanya lebih dari satu tahun) sehingga perlu lebih dipikirkan keberadaannya oleh para manajer keuangan perusahaan.

\section{Metodologi Penelitian}

Penelitian yang dilakukan merupakan jenis penelitian kuantitatif, dimana dalam melaksanakan penelitian ini data yang digunakan adalah data sekunder. Data sekunder yang dimaksud adalah sumber data penelitian yang diperoleh melalui media perantara atau secara tidak langsung yang berupa buku, catatan, bukti yang telah ada, atau arsip baik yang dipublikasikan maupun yang tidak dipublikasikan secara umum. Data yang telah menjadi dasar 
penelitian merupakan laporan keuangan historis tahunan perusahaan jasa sektor keuangan yang tercatat di Bursa Efek Indonesia (BEI) periode 2014 - 2018.

\section{Tabel 1.1}

Daftar Sampel Perusahaan Jasa Sektor Keuangan Perbankan

\begin{tabular}{|c|c|l|}
\hline No & Kode Perusahaan & Nama Perusahaan \\
\hline 1 & AGRO & Bank Rakyat Indonesia Agro Niaga Tbk \\
\hline 2 & AGRS & Bank Agris Tbk \\
\hline 3 & BABP & Bank MNC Internasional Tbk \\
\hline 4 & BACA & Bank Capital Indonesia Tbk \\
\hline 5 & BBCA & Bank Central Asia Tbk \\
\hline 6 & BBKP & Bank Bukopin Tbk \\
\hline 7 & BBMD & Bank Mestika Dharma Tbk \\
\hline 8 & BBNI & Bank Negara Indonesia (Persero) Tbk \\
\hline 9 & BBRI & Bank Rakyat Indonesia (Persero) Tbk \\
\hline 10 & BBTN & Bank Tabungan Negara (Persero) Tbk \\
\hline 11 & BCIC & Bank J Trust Indonesia Tbk \\
\hline 12 & BDMN & Bank Danamon Indonesia Tbk \\
\hline 13 & BEKS & Bank Pembangunan Daerah Banten Tbk \\
\hline 14 & BINA & Bank Ina Perdana Tbk \\
\hline 15 & BJBR & Bank Jabar Banten Tbk \\
\hline 16 & BJTM & Bank Pembangunan Daerah Jawa Timur Tbk \\
\hline 17 & BKSW & Bank QNB Indonesia Tbk \\
\hline 18 & BMAS & Bank Maspion Indonesia Tbk \\
\hline 19 & BMRI & Bank Mandiri (Persero) Tbk \\
\hline 20 & BNBA & Bank Bumi Arta Tbk \\
\hline 21 & BNGA & Bank CIMB Niaga Tbk \\
\hline 22 & BNII & Bank Maybank Indonesia Tbk \\
\hline 23 & BNLI & Bank Permata Tbk \\
\hline 24 & BSIM & Bank Sinar Mas Tbk \\
\hline 25 & BSWD & Bank of India Indonesia Tbk \\
\hline 26 & BTPN & Bank Tabungan Pensiunan Nasional Tbk \\
\hline 27 & BVIC & Bank Victoria International Tbk \\
\hline 28 & DNAR & Bank Dinar Indonesia Tbk \\
\hline 29 & INPC & Bank Artha Graha International Tbk \\
\hline 30 & MAYA & Bank Mayapada International Tbk \\
\hline 31 & MCOR & Bank China Constrution Bank Ind.Tbk \\
\hline 32 & MEGA & Bank Mega Tbk \\
\hline 33 & NOBU & Bank Nationalnobu Tbk \\
\hline 34 & PNBN & Bank Pan Indonesia Tbk \\
\hline 35 & SDRA & Bank Woori Saudara Indonesia 1906 Tbk \\
\hline & & \\
\hline & & \\
\hline & &
\end{tabular}

Dalam penelitian ini, jenis uji yang digunakan adalah Uji $\mathrm{F}$ dan Uji Koefisien Determinasi $\left(\mathrm{R}^{2}\right)$.

\section{Hasil \& Kesimpulan}

Hasil uji F pada tabel 4.8 Menunjukkan bahwa nilai F hitung sebesar 9,017 bertanda positif dengan nilai sig $0,000<0,05(\alpha=0,05)$. Hal ini menunjukkan bahwa variabel profitabilitas, likuiditas dan ukuran perusahaan berpengaruh signifikan terhadap struktur modal. 


\section{Tabel 4.2}

Uji F

ANOVA $^{\mathrm{a}}$

\begin{tabular}{|c|c|c|c|c|c|c|}
\hline \multicolumn{7}{|c|}{$\mathrm{ANOVA}^{\mathrm{a}}$} \\
\hline \multicolumn{2}{|c|}{ Model } & $\begin{array}{l}\text { Sum of } \\
\text { Squares }\end{array}$ & df & Mean Square & $\mathrm{F}$ & Sig. \\
\hline \multirow[t]{3}{*}{1} & Regression & 169.730 & 3 & 56.577 & 9.017 & $.000^{\mathrm{b}}$ \\
\hline & Residual & 1072.893 & 171 & 6.274 & & \\
\hline & Total & 1242.623 & 174 & & & \\
\hline
\end{tabular}

a. Dependent Variable: DER

b. Predictors: (Constant), SIZE, LDR, NPM

Dari hasil penelitian bahwa dalam model didapatkan nilai adjusted $R$ square sebesa 0,137 atau $13,7 \%$. Hal ini menunjukkan bahwa kemampuan variabel independen yaitu profitabilitas. Pertumbuhan perusahaan, ukuran perusahaan, struktur aktiva, dan likuiditas perusahaan secara simultan memiliki pengaruh sebesar $13,7 \%$ terhadap struktur modal, sedangkan sisanya sebesar $86,3 \%$ dijelaskan oleh variabel lain yang tidak diamati dalam penelitian ini.

\begin{tabular}{|c|c|c|c|c|}
\hline \multicolumn{5}{|c|}{ Tabel 4.3 Uji Koefisien Determinasi $\left(R^{2}\right)$} \\
\hline Model & $\mathrm{R}$ & R Square & $\begin{array}{c}\text { Adjusted R } \\
\text { Square }\end{array}$ & $\begin{array}{l}\text { Std. Error of } \\
\text { the Estimate }\end{array}$ \\
\hline 1 & $.370^{\mathrm{a}}$ & .137 & .121 & $\begin{array}{r}2.50484131819 \\
7792\end{array}$ \\
\hline
\end{tabular}

Kesimpulan dalam penelitian ini adalah bahwa terdapat pengaruh signifikan dari ukuran perusahaan, profitabilitas dan likuiditas pada perusahaan jasa sektor keuangan perbankan yang terdaftar di Bursa Efek Indonesia pada tahun 2014 - 2018. Hal ini terbukti dengan uji F.

\section{Daftar Pustaka}

Andayani, Ida Ayu Kade Trisia, dan Ketut Alit Suardana. (2018). Pengaruh Profitabilitas, Likuiditas, Pertumbuhan Penjualan dan Struktur Aktiva pada Struktur Modal. Jurnal Akuntansi. Vol.24, No.1, Juli 2018

Brigham, Eugene F. dan Michael C. Ehrhardt. (2011). Financial Management : Theory and Practice $\left(13^{\text {th }}\right.$ ed.). Mason, USA : South-Western Cengage Learning

Dwilestari, Anita. (2010). Pengaruh Struktur Aktiva, Pertumbuhan, dan Likuiditas terhadap Struktur Modal Perusahaan . Jurnal Riset Akuntansi dan Keuangan, 2010

Ghozali, Imam. (2017). EKONOMETRIKA Teori, Konsep dan Aplikasi denan IMB SPSS. Yogyakarta : Badan Penerbit Universitas Diponegoro Semarang

Mihaela, Herciu Mihaela dan Ogrean Claudia. (2017). Does Capital Structure Influence Company Profitability?. Studies in Business and Economics. Vol 12, Issue 3, 2017

Mokhova, Natalia dan Marek Zinecker. (2013). The Determinants of Capital Structure : The Evidence from the European Union. Acta Universitatis Agriculturae et Silviculturae Mendelianae Brunensis. Vol 61, Issue 7, 2013

www.idx.com 